\title{
Section XIV: Humanitarian Assistance
}

Rule 119

(a) If the civilian population in occupied territory is not adequately provided with food, medical supplies, clothing, bedding, means of shelter or other supplies or care essential to its survival, the Occupying Power must undertake, facilitate, or allow relief consignments, which are humanitarian and impartial in character, and conducted without adverse distinction.

(b) If the Occupying Power does not provide the civilian population in the occupied territory with adequate humanitarian relief as provided for in (a), it must consent to humanitarian relief consignments by other States or impartial international humanitarian organizations as described in Rules 120 and 121.

\section{Commentary}

1. "Humanitarian aid" or "humanitarian relief" is not defined by treaty LOAC, ${ }^{1}$ but GC/I-IV and AP/I provide the key elements thereof: "medical and hospital stores", "essential foodstuffs, clothing and tonics intended for children under fifteen, expectant mothers and maternity cases", "other articles if the resources of the occupied territory are inadequate", 3 "clothing", and "bedding, means of shelter, other supplies essential to the survival of the civilian population". 5

\footnotetext{
${ }^{1}$ For the purposes of this Manual the expressions "humanitarian aid", "humanitarian assistance" and 'humanitarian relief' are synonymous.

${ }^{2}$ GC/IV, see chapter "Section I: Outer Space", fn. 19, Article 23.

${ }^{3} \mathrm{GC} / \mathrm{IV}$, ibid, Article 55.

${ }^{4} \mathrm{GC} / \mathrm{IV}$, ibid, Article 59.

${ }^{5}$ AP/ I, see chapter "Section I: Outer Space", fn. 13, Article 69 (1).
} 
2. The obligation to take care of the needs of the civilian population is most clearly regulated with regard to occupied territories: the Occupying Power has the duty of "ensuring the food and medical supplies of the population"- to the fullest extent of the means available to it—and it is obliged to, in particular, "provide necessary foodstuffs, medical stores and other articles if the resources of the occupied territory are inadequate". 6

3. In case the needs of the "whole or part" of the civilian population cannot be met by the Occupying Power, the latter shall agree to humanitarian relief consignments for the benefit of the said population, which may be undertaken either by States or impartial humanitarian organizations, and shall facilitate them "by all the means at its disposal"?

4. In a situation of occupation, the Occupying Power may verify that the relief consignments are purely humanitarian in their nature (see Commentary to Rule 125(a)), a process that may take some time, but it cannot withhold consent indefinitely.

\section{Rule 120}

(a) If the civilian population of any territory under the control of a party to the conflict, other than occupied territory, is not adequately provided with food, medical supplies, clothing, bedding, means of shelter or other supplies or care essential to its survival, relief consignments, which are humanitarian and impartial in character and conducted without adverse distinction, must be undertaken and facilitated.

(b) Where humanitarian relief consignments are offered by other States or impartial international humanitarian organizations, this can be undertaken only subject to the consent of the territorial State.

(c) Such consent cannot be withheld arbitrarily.

\section{Commentary}

1. This Rule deals with international armed conflicts in situations that do not entail belligerent occupation. As for non-international armed conflicts, see Rule 129.

2. It is primarily a responsibility for each State to take care of the humanitarian needs of the civilian population within its territory. Hence, the territorial State has the primary role in the initiation, organization, coordination, and implementation of humanitarian assistance within its territory. ${ }^{8}$

\footnotetext{
${ }^{6} \mathrm{GC} / \mathrm{IV}$, see chapter "Section I: Outer Space", fn. 19, Article 55.

${ }^{7} \mathrm{GC} / \mathrm{IV}$, ibid, art. 59.

${ }^{8}$ See UN GA Res 46/82 (1991), Annex, paragraph 4.
} 
3. With regard to international armed conflicts, the current status of the law is that consent of the controlling State is required. This follows explicitly from Article 70(1) of AP/I. ${ }^{9}$

4. It is generally agreed, however, that consent cannot be withheld arbitrarily. ${ }^{10}$

\section{Rule 121}

Withholding of consent can be arbitrary if it is not compatible, inter alia, with other obligations under applicable principles and rules of LOAC, or if it is unreasonable given the needs of the civilian population in the prevailing circumstances.

\section{Commentary}

1. The phrase "applicable principles and rules of LOAC" is explained in paragraph 5 of the Commentary to Rule 2.

2. With regard to the notion of "arbitrarily", justification for the denial of an offer of humanitarian assistance is crucial. Withholding consent to external assistance is not arbitrary where:

a. A State is capable of providing, and willing to provide, an adequate and effective humanitarian assistance on the basis of its own resources;

b. An affected State has accepted appropriate and sufficient assistance from elsewhere; or

c. The relevant offer is not extended in accordance with the principles of neutrality, impartiality, and non-discrimination, as laid down in Rule 127. Conversely, where an offer of assistance is made in accordance with the foregoing and no alternate sources of humanitarian assistance are available, there would be a strong inference that a decision to withhold consent is arbitrary. ${ }^{11}$

\section{Rule 122}

Consent is not required if the Security Council has made use of its powers under the Charter of the United Nations to authorize in a binding manner relief actions for the civilian population in any situation of armed conflict.

\footnotetext{
${ }^{9}$ AP/ I, see chapter "Section I: Outer Space", fn. 13, Article 70 (1); "Parties" in plural, since the consignments may travel through several countries.

${ }^{10}$ See the position in the US DoD Manual, see chapter "Section II: Cyber Operations", fn. 4, para 17.8.1: "States may withhold consent for, inter alia, legitimate military reasons, but should not arbitrarily withhold consent".

${ }^{11}$ Report ILC, 66th Session, No. A/69/10 (UN, New York, 2014), Chapter V.
} 


\section{Commentary}

1. This Rule is based on the powers vested in the Security Council by Chapter VII of the Charter of the United Nations to authorize measures binding upon States.

2. Refusal to abide by a binding decision of the Security Council is, by definition, arbitrary as well as unlawful under Article 25 of the Charter of the United Nations.

\section{Rule 123}

Offers to provide humanitarian relief consignments to the civilian population of another State shall not be regarded as:

(a) Interference in the armed conflict;

(b) An unfriendly act; or

(c) An interference in the domestic affairs of the State concerned.

\section{Commentary}

1. Subparagraphs (a) and (b) are derived from AP/I 70 (1).

2. This Rule is embedded in the judgement of the ICJ in the Nicaragua Case.

3. As clarified by the court in the Nicaragua Case, this Rule is confined to the "provision of food, clothing, medicine and other humanitarian assistance, and it does not include the provision of weapons, weapons systems, ammunition, or other equipment, vehicles, or material which can be used to inflict serious bodily harm or death". This requirement reflects the prohibition against intervening in matters that are essentially internal to the State concerned. In this regard the ICJ stated that "there can be no doubt that the provision of strictly humanitarian aid to persons or forces in another country, whatever their political affiliations or objectives, cannot be regarded as unlawful intervention, or as in any other way contrary to international law". 12

\section{Rule 124}

Humanitarian relief consignments may be provided in accordance with Rule 119 and 120 either by States or by impartial humanitarian organizations, such as the International Committee of the Red Cross.

\section{Commentary}

1. There are no formal requirements as to who may seek to provide humanitarian relief consignments subject to the conditions set out in Rule 125.

2. The International Committee of the Red Cross is the paradigmatic example of an impartial humanitarian organization, but of course it is not the only one.

\footnotetext{
${ }^{12}$ ICJ, Nicaragua v. United States of America, see chapter "Section X: Civil Aviation and Civilian Airliners", fn. 3, paragraphs 242 and 97.
} 
Rule 125

(a) States should allow and facilitate rapid and unimpeded passage of humanitarian relief consignments, equipment and personnel in accordance with Rules 119 and 120, subject to technical arrangements.

\section{Commentary}

1. This Rule deals in a combined manner with occupied and non-occupied territory. However, it must be underscored that in occupied territory, the obligation borne by the Occupying Power (under Rule 119) is unqualified. ${ }^{13}$

2. Although the distribution of humanitarian relief consignments must not be arbitrarily impeded, it may be subjected to technical arrangements.

3. Obviously, compliance with technical arrangements may be time consuming. However, it must not become an excuse for an arbitrary withholding of consent to humanitarian relief action.

(b) Technical arrangements may derive from operational exigencies and may include matters such as:

i. Verification that the relief supplies do not contain weapons, munitions, military equipment or other supplies reasonably expected to be used for military purposes;

ii. Regulation of the relief consignment in order to prescribe times and routes in such a way as to avoid hampering military operations and to conform to the maximum extent with security requirements;

iii. Establishment of air corridors for the transit of relief air transports; or

iv. Organisation of air drops or landings.

\section{Commentary}

1. The mentioned list is illustrative and not exhaustive.

(c) Technical arrangements under sub-paragraph (b) must in no case be misused in order to make the provision of relief consignments inoperative or to delay the forwarding of relief unduly.

\section{Rule 126}

(a) Personnel of impartial humanitarian relief organizations, acting within their mandates, must be respected and protected and must not be made the object of attack or of any action that arbitrarily prevents them from discharging their mandate. The protection extends to their humanitarian transports, installations, goods and activities.

\footnotetext{
${ }^{13}$ See 1949 Geneva Convention Relative to the Protection of Civilian Persons in Time of War, chapter "Section I: Outer Space", fn. 19.
} 
(b) Only in the case of imperative military necessity may the activities of personnel of impartial humanitarian relief organizations be limited or their movements temporarily restricted.

\section{Commentary}

1. Paragraph (a) of this Rule is based on Article 71(2) of AP/I and customary LOAC, as expressed in Article 8(2)(b)(iii) and Article 8(2)(e)(iii) of the Rome Statute. ${ }^{14}$ Paragraph (b) of this Rule is based on Article 71(3) of AP/I.

2. Although AP/I provides that the protection of humanitarian relief personnel applies only to "approved", i.e. authorized, humanitarian personnel as such, the overwhelming majority of practice does not specify this condition. ${ }^{15}$ The notion of authorization refers to the consent received from the party to the conflict concerned to work in areas under its control. ${ }^{16}$ However, as Article 71(3) provides, "Each Party in receipt of relief consignments shall, to the fullest extent practicable, assist the relief personnel referred to in paragraph 1 in carrying out their relief mission. Only in case of imperative military necessity may the activities of the relief personnel be limited or their movements temporarily restricted."

3. United Nations personnel delivering humanitarian aid enjoy specific protection under the Convention on the Safety of United Nations and Associated Personnel, as their safety and security shall be ensured and they shall not be made the object of attack or of any action that prevents them from discharging their mandate. ${ }^{17}$

4. The word "respect" means "to spare, not to attack", while "protect" means "to come to someone's defence, to lend help and support." $"$ "Thus, it is prohibited to attack, to kill, to maltreat or injure humanitarian relief personnel in any way, and there is also an obligation to come to their rescue.

5. The obligation to respect and protect relief personnel applies to all the parties to the conflict, which should instruct their armed forces not to attack such personnel.

\footnotetext{
${ }^{14}$ See as well $A M W$ Manual, see chapter "Section I: Outer Space", fn. 1, at page $36 \mathrm{ff}$. and UN Security Council resolutions 2175 (2014) and 2286 (2016)

${ }^{15}$ The US DoD Law of War Manual, see chapter “Section II: Cyber Operations", fn. 2, at page 1035, does not specifically require the humanitarian personnel to be approved or authorized, but notes that the safety of humanitarian personnel is a legitimate consideration for a Government in consenting to their operations.

${ }^{16}$ AP/I, see chapter "Section I: Outer Space", fn. 13, Article 71(1), and CIHL, see chapter "Section XI: Destruction of Property", fn. 1, Rule 31.

${ }^{17}$ Convention on the Safety of UN and Associated Personnel (1994), UNTS, vol. 2051, page 363, Article 7.

${ }^{18}$ AP/Commentary, see chapter "Section VIII: Civilians Participating in Unmanned Operations", fn. 1, to Article 10, para 446.
} 


\section{Rule 127}

Humanitarian relief personnel, transports, installations, goods and activities may lose special protection if the relief actions are not:

\section{Commentary}

1. Non-compliance with the conditions listed in subparagraph (a) through (d) may deprive the humanitarian personnel and objects of their special protections but does not affect their civilian protection unless the personnel are directly participating in hostilities or, in the case of objects, they are effectively contributing to the enemy's military action.

(a) Exclusively humanitarian and impartial in character;

\section{Commentary}

1. See Rule 119 (a).

(b) Conducted without any adverse distinction;

\section{Commentary}

1. LOAC requires non-discrimination in its application and prohibits adverse discrimination based on sex, race, nationality, religion, political opinions or any other similar criteria.

2. The prohibition of adverse distinction does not imply that special treatment of persons with particular needs would be prohibited. ${ }^{19}$

3. It would not be arbitrary for a State to refuse to give consent to a provision of humanitarian assistance that would be based on the making of an adverse distinction among the recipients of that assistance.

(c) Executed in accordance with the terms of their mission; or

\section{Commentary}

1. The mission refers to the agreement concluded between the organisation or neutral State providing the relief action and the concerned State.

(d) In compliance with the technical arrangements issued by the States or parties concerned.

\section{Commentary}

1. For examples of technical arrangements, see Rule 125 (b).

\footnotetext{
${ }^{19}$ AP/Commentary, ibid, to Article 70(2), para 2825.
} 


\section{Rule 128}

Whenever circumstances permit, parties to the conflict should suspend attacks in order to permit passage of humanitarian relief consignments.

\section{Commentary}

1. Due to an insufficiency of State practice and opinio juris supporting this Rule, the Group of Experts decided to avoid the use of mandatory language (such as "must" or "shall").

2. The notion of "circumstances permit" is generally understood to reflect considerations of military necessity.

\section{Rule 129 \\ In principle, the Rules relating to the provision of humanitarian assistance apply to both international and non-international armed conflicts mutatis mutandis.}

\section{Commentary}

1. AP/II provides that relief actions in non-international armed conflicts should be undertaken subject to the consent of the High Contracting Party concerned. As stipulated in Article 18 (2) of AP/II, such consent is always required, i.e., even in situations where an area controlled by non-State actors borders on an adjacent State so that humanitarian access can take place without passing through areas controlled by the incumbent Government.

2. Although de jure there is no treaty requirement of insurgent consent, de factoshould the insurgents be in control of the relevant territory-their consent to the humanitarian operation will become indispensable for the provider of humanitarian assistance. Efforts must, however, also be made to secure the consent of the incumbent Government.

Open Access This chapter is licensed under the terms of the Creative Commons Attribution 4.0 International License (http://creativecommons.org/licenses/by/4.0/), which permits use, sharing, adaptation, distribution and reproduction in any medium or format, as long as you give appropriate credit to the original author(s) and the source, provide a link to the Creative Commons licence and indicate if changes were made.

The images or other third party material in this chapter are included in the chapter's Creative Commons licence, unless indicated otherwise in a credit line to the material. If material is not included in the chapter's Creative Commons licence and your intended use is not permitted by statutory regulation or exceeds the permitted use, you will need to obtain permission directly from the copyright holder.

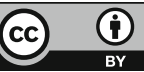

